\title{
Genetic analysis for seed size in three crosses of chickpea (Cicer arietinum L.)
}

\author{
Shivali Sharma, H. D. Upadhyaya ${ }^{1}$, C. L. L. Gowda, Shiv Kumar, and Sube Singh \\ International Crops Research Institute for the Semi-Arid Tropics (ICRISAT), Patancheru, Hyderabad, PO, 502324, \\ AP, India. Received 30 January 2012, accepted 7 December 2012.
}

\begin{abstract}
Sharma, S., Upadhyaya, H. D., Gowda, C. L. L., Kumar, S. and Singh, S. 2013. Genetic analysis for seed size in three crosses of chickpea (Cicer arietinum L.). Can. J. Plant Sci. 93: xxx-xxx. Seed size (determined by 100-seed weight) is an important component of trade and yield in chickpea (Cicer arietinum L.). The present investigation was undertaken to study the possibility of maternal inheritance for seed size and to estimate relative importance of additive and non-additive gene effects on seed size in three chickpea crosses involving two desi (ICC 5002 and ICC 7672) and two kabuli (ICC 11255 and ICC 17109) genotypes. The study included parents, $F_{1}, F_{2}$, backcross generations, and their reciprocals. Differences in the reciprocal mean 100 -seed weight of $F_{1}, F_{2}$, and backcross generations were not detected in any cross. No definite major gene segregation pattern was observed in the $\mathrm{F}_{2}$ generation, and the continuous variation observed indicated quantitative inheritance. Generation mean analysis indicated the presence of additive gene effects controlling seed size in three crosses. Additive $\times$ additive type of non-allelic interactions were found significant in desi $\times$ kabuli crosses, ICC $5002 \times$ ICC 17109 and ICC $7672 \times$ ICC 11255 . The selection and breeding procedure may be modified for maximum exploitation of the fixable additive $\times$ additive epistasis by delaying selection in later generations and by maintaining large populations prior to selection for maximum recombination of genes to occur.
\end{abstract}

Key words: Gene effects, epistasis, generation mean analysis, maternal effects, quantitative inheritance

\begin{abstract}
Sharma, S., Upadhyaya, H. D., Gowda, C. L. L., Kumar, S. et Singh, S. 2013. Analyse génétique du calibre des graines de trois hybrides du pois chiche (Cicer arietinum L.). Can. J. Plant Sci. 93: xxx-xxx. Le calibre des graines (déterminé à partir du poids de cent graines) est un important paramètre commercial et facteur de rendement chez le pois chiche (Cicer arietinum L.). L'étude a été effectuée pour vérifier si la taille des graines est un caractère transmis par la mère et pour estimer l'importance relative des effets génétiques additifs ou pas sur le calibre des semences de trois hybrides de pois chiche combinant deux génotypes desi (ICC 5002 et ICC 7672) et deux génotypes kabuli (ICC 11255 et ICC 17109). La recherche portait sur les parents, la $\mathrm{F}_{1}, \mathrm{la}_{2}$, les rétrocroisements et leurs réciproques. Aucun écart n'a été observé au niveau de la moyenne réciproque du poids de cent graines pour la $F_{1}$, la $F_{2}$, et les rétrocroisements, peu importe l'hybride. On n'a relevé non plus aucune ségrégation définie de gènes importants dans la $F_{2}$ et la variation continue observée laisse croire à une hérédité quantitative. L'analyse des moyennes générationnelles indique que des effets additifs contrôlent le calibre des graines chez trois hybrides. Des interactions non alléliques de type additif $\times$ additif significatives ont été notées dans les croisements desi $\times$ kabuli, ICC $5002 \times$ ICC 17109 et ICC $7672 \times$ ICC 11255 . On pourrait modifier la méthode de sélection et d'hybridation de manière à exploiter au maximum l'épistasie additif $\times$ additif qu'il est possible de fixer en retardant la sélection aux générations ultérieures et en préservant de vastes populations avant puis en procédant à l'hybridation de façon à obtenir la plus grande recombinaison des gènes possible.
\end{abstract}

Mots clés: Effets génétiques, épistasie, analyse de la moyenne générationnelle, effets maternels, hérédité quantitative

Chickpea (Cicer arietinum L.) is a highly nutritious pulse crop and ranks third among the food legumes cultivated in the world. It is grown in more than 50 countries on 11.98 million ha with 10.92 million tons of production and $911 \mathrm{~kg} \mathrm{ha}^{-1}$ average productivity (Food and Agriculture Organization 2010; accessed on 2012 Jun. 12). In chickpea, seed size is an important component of yield, and trade (Singh and Paroda 1986; Singh 1987). Screening of more than 16000 accessions from the world collection of chickpea germplasm at the International Crops Research Institute for the Semi-Arid Tropics

\footnotetext{
${ }^{1}$ Corresponding author (e-mail: h.upadhyaya@, cgiar.org).
}

(ICRISAT), Patancheru, India, revealed a wide range of variability for seed size (4-63 g 100-seed weight) (Upadhyaya 2003); More than $60 \%$ of accessions have a 100 -seed weight of 9 to $14 \mathrm{~g}$, and only a few accessions (five accessions) were found to be small seeded $(<5 \mathrm{~g}$ 100 -seed weight). On the basis of seed shape and size, two distinct types of chickpea are recognized: the angular shaped, dark colored and usually small seeded desi type and, the owl head shaped, beige colored and usually large seeded kabuli type. A wide range of genetic variability is present for seed size in both the types. Diversity in seed size has been associated with the geographical distribution of the genotypes (Upadhyaya 2003) and different fitness components of seedlings and adult plants (Narayana et al. 1981; Dahiya et al. 1985). 


\section{CANADIAN JOURNAL OF PLANT SCIENCE}

To understand the inheritance pattern of phenotypic variation in seed size, the genes responsible for this variation need to be identified. In earlier reports, both polygenic (minor genes) as well as monogenic/oligogenic (major genes) inheritance of seed size have been reported. Studies considering seed size as a quantitative trait showing polygenic inheritance have been reported by previous researchers (Kumar and Singh 1995; Malhotra et al. 1997) and the genetic analysis has mainly been confined to estimating gene effects (Singh et al. 1992, 1993; Kumar and Singh 1995) and heritability (Kumar and Singh 1995). Studies considering seed size as a qualitative trait have reported monogenic (Argikar 1956), digenic (Ghatge 1993), and oligogenic (Patil and D'Cruze 1964) inheritance. Upadhyaya et al. (2006) reported that the seed size in chickpea was controlled by two genes with dominance epistasis. The parental genotypes were designated as $\mathrm{Sd}_{1} \mathrm{Sd}_{1} \mathrm{Sd}_{2} \mathrm{Sd}_{2}$ for ICC 11255 (12g 100-seed weight) and $\mathrm{sd}_{1} \mathrm{sd}_{1} \mathrm{Sd}_{2} \mathrm{Sd}_{2}$ for ICC 5002 (5g 100-seed weight), where $\mathrm{Sd}_{1}$ is epistatic to $\mathrm{Sd}_{2}$ and $\mathrm{sd}_{2}$ alleles. In another study involving two medium seeded kabuli parents ICCV 2 and L 550 both having 18-19 g 100-seed weight, Upadhyaya et al. (2011) reported that seed size in these genotypes is controlled by two genes exhibiting additive effects where each parent has one pair of alleles with increasing effect at one locus in homozygous form. They designated the genotype of ICCV 2 as $\mathrm{Sd}_{3} \mathrm{Sd}_{3} \mathrm{Sd}_{4} \mathrm{Sd}_{4}$ and $\mathrm{L} 550$ as $\mathrm{sd}_{3} \mathrm{Sd}_{3} \mathrm{Sd}_{4} \mathrm{Sd}_{4}$, where both the $\mathrm{Sd}_{3}$ and $\mathrm{Sd}_{4}$ alleles have increasing additive effect. Further, the genetic analysis using molecular markers detected two quantitative trait loci (QTL) for seed size in intraspecific kabuli $\times$ desi (Cho et al. 2002; Cobos et al. 2007; Hossain et al. 2010), desi $\times$ desi (Radhika et al. 2007) and interspecific Cicer arietinum $\times C$. reticulatum (Cobos et al. 2007, 2009) recombinant inbred line populations in chickpea explaining up to $52 \%$ of the total phenotypic variation.

In most of these previous studies (e.g., Kumar and Singh 1995; Upadhyaya et al. 2006; Upadhyaya et al. 2011), parents utilized had a limited range of available variation for seed size. For ascertaining the genetic nature of inheritance of seed size, it is important to use a greater range of variation by involving parents of extreme seed size from desi and kabuli types in the study. In addition, the analysis of reciprocal crosses in several species including field pea suggests the strong maternal effects in the inheritance of seed size (Davies 1975; Lemontey et al. 2000). The present study therefore included two chickpea genotypes each of both desi and kabuli types representing the low and high extremes for 100-seed weight. Chickpea genotypes having known major genes for seed size, ICC $11255\left(\mathrm{Sd}_{1} \mathrm{Sd}_{1} \mathrm{Sd}_{2} \mathrm{Sd}_{2}\right)$ and ICC $5002\left(\operatorname{sd}_{1} \mathrm{Sd}_{1} \mathrm{Sd}_{2} \mathrm{Sd}_{2}\right)$ were included with large seeded types of unknown genetic constitution to study the inheritance of seed size in terms of maternal effect and the relative importance of additive and non-additive gene effects in three crosses.

\section{MATERIALS AND METHODS}

\section{Plant Material}

The global chickpea germplasm collection at ICRISAT, Patancheru, India, has wide range of variability for seed size. Four chickpea genotypes that show almost tenfold difference in their mean 100-seed weight, representing extremes in the spectrum of diversity, were selected for this study. ICC $5002\left(\operatorname{sd}_{1} \operatorname{sd}_{1} \operatorname{Sd}_{2} \mathrm{Sd}_{2}\right)$, a desi type line from India with very small seeds (5 g 100-seed weight), ICC $11255\left(\mathrm{Sd}_{1} \mathrm{Sd}_{1} \mathrm{sd}_{2} \mathrm{sd}_{2}\right)$, a kabuli type landrace from Pakistan with small seeds (12 g 100-seed weight) (Upadhyaya et al. 2006), two large seeded accessions ICC 7672, a desi landrace from Morocco, having a 100-seed weight of $49 \mathrm{~g}$, and ICC 17109, a kabuli line from Mexico having $60 \mathrm{~g} \mathrm{100-seed} \mathrm{weight} \mathrm{were} \mathrm{used} \mathrm{in}$ study. These germplasm lines were crossed to generate six crosses, ICC $5002 \times$ ICC 17109 and ICC $17109 \times$ ICC 5002 (desi $\times$ kabuli), ICC $11255 \times$ ICC 17109 and ICC $17109 \times$ ICC 11255 (kabuli $\times$ kabuli), and ICC $11255 \times$ ICC 7672 and ICC $7672 \times$ ICC 11255 (desi $\times$ kabuli).

Crosses were made at ICRISAT, Patancheru in the 1998-1999 post-rainy season. Each of the six crosses were crossed to both their respective parents to generate backcross generations $\left(\mathrm{BC}_{1} \mathrm{P}_{1}\right.$ and $\left.\mathrm{BC}_{1} \mathrm{P}_{2}\right)$ and also selfed to produce $F_{2}$ generation in the 1999-2000 postrainy season. In the present study, $\mathrm{F}_{1}$ (generation) refer to the seeds on $F_{1}$ plants and $F_{2}$ (generation) are the seeds on $\mathrm{F}_{2}$ plants.

Parents, $F_{1}, F_{2}$ and backcross generations of three crosses along with their reciprocals were evaluated in the un-replicated trial during the 2000-2001 postrainy season at ICRISAT, Patancheru in Vertisol (Kasireddipally series - isohypothermic Typic Pellustert) (El-Swaify et al. 1985). The generations within a cross were randomized. The plot size varied for different generations. Parents, $\mathrm{F}_{1}$ and backcross generations were grown in two-row plots. The $\mathrm{F}_{2}$ generations were grown in 7 to 42 rows (population size: 121 to 794 plants), depending on the quantity of seeds available in three crosses. The rows were $4 \mathrm{~m}$ long and $60 \mathrm{~cm}$ apart with plants spaced at $20 \mathrm{~cm}$ within a row. Seeds were treated with a mixture of $2 \mathrm{~g}$ thiram and $1 \mathrm{~g}$ carbendazim per kilogram of seeds before planting to avoid infestation by soil-borne pathogens. Sowing was done manually in last week of October 2000. Care was taken to sow the seeds at uniform depth $(5 \mathrm{~cm})$. The crop was protected from pod borer (Helicoverpa armigera) by spraying $20 \mathrm{~mL} \mathrm{ha}^{-1}$ Indoxacarb in $300 \mathrm{~L}$ water as soon as the young caterpillars were noticed and the plots were kept weedfree by manual weeding. The crop received $18 \mathrm{~kg} \mathrm{~N}$ and $46 \mathrm{~kg} \mathrm{P}_{2} \mathrm{O}_{5} \mathrm{ha}^{-1}$ basal fertilizers by using $100 \mathrm{~kg} \mathrm{ha}^{-1}$ diammonium phosphate and three irrigations $(7 \mathrm{~cm}$ water per irrigation). Recommended crop production practices were followed for chickpea production (Yadav et al. 2007). 
SHARMA ET AL. - GENETIC ANALYSIS FOR SEED SIZE IN CHICKPEA

\section{Data Collection and Analysis}

The 100-seed weight was chosen as measure of seed size and was recorded on all the plants available (Table 1) in different generations. Mature pods from each plant were harvested separately, and 100-seed weight of each plant was calculated as:

(Weight of all seeds/number of seeds) $\times 100$

Based on the 100-seed weight data, the segregation pattern for seed size in the $\mathrm{F}_{2}$ generation (the seeds on $\mathrm{F}_{2}$ plants) was examined. When the data did not fit into the qualitative mode of inheritance in the three crosses, the data were subjected to quantitative genetic analysis (Upadhyaya et al. 2010).

The mean, variance, range, and standard error of 100seed weight in the $\mathrm{P}_{1}, \mathrm{P}_{2}, \mathrm{~F}_{1}, \mathrm{~F}_{2}, \mathrm{BC}_{1} \mathrm{P}_{1}$, and $\mathrm{BC}_{1} \mathrm{P}_{2}$ generations were calculated. The estimated means of $\mathrm{F}_{1}$, $\mathrm{F}_{2}$, and backcross generations were compared with their reciprocals using t-test to examine the maternal effect, if present. Reciprocal differences were not observed, and hence the data were pooled for generation mean analysis.

\section{Generation Mean Analysis}

The generation means of seed size were used to perform a simple scaling test to test the adequacy of additivedominance model. The four scaling tests, as given by Mather (1949) and Hayman and Mather (1955) were used as follows: $\mathrm{A}=2 \mathrm{BC}_{1} \mathrm{P}_{1}-\mathrm{P}_{1}-\mathrm{F}_{1} ; \mathrm{B}=2 \mathrm{BC}_{1} \mathrm{P}_{2}-\mathrm{P}_{2}-\mathrm{F}_{1}$; $\mathrm{C}=4 \mathrm{~F}_{2}-2 \mathrm{~F}_{1}-\mathrm{P}_{1}-\mathrm{P}_{2}$; and $\mathrm{D}=2 \mathrm{~F}_{2}-\mathrm{BC}_{1} \mathrm{P}_{1}-\mathrm{BC}_{1} \mathrm{P}_{2}$. Significance of any one or two scaling tests implies the inadequacy of additive-dominance model. The A and B scaling tests provide the evidence for the presence of additive $\times$ additive $[i]$, additive $\times$ dominance $[j]$ and dominance $\times$ dominance $[l]$ types of epistasis. The $\mathrm{C}$ and $\mathrm{D}$ scaling tests provide a test for additive $\times$ additive $[i]$, and dominance $\times$ dominance $[l]$ types of epistasis.
Under the inadequacy of additive-dominance model, the joint scaling test (Cavalli 1952) as described by Mather and Jinks (1982) was used to obtain information on the nature of gene effects involved in the genetic control of seed size. The parameters estimated were mean effects $[\mathrm{m}]$, additive [d] and dominance [h] gene effects and three types of epistasis (i, j, and 1). These parameters were estimated by weighted least square method. The purpose of using weights was to account for differential precision with which means of different generations were estimated by virtue of the varying sample size. The weights were calculated as the inverse of the variance of generation means. The generation means were predicted based on the parameters estimated and the test of goodness-of-fit was conducted using chi-square $\left(\chi^{2}\right)$ statistic. All possible 32 models developed from including or excluding one or more of the five parameters $(\mathrm{d}$, $\mathrm{h}, \mathrm{i}, \mathrm{j}$, and 1) with [m] were fitted using a general linear model set-up in GenStat software (Payne et al. 2009). Of these 32 models, those models which showed insignificant deviation compared with a tabulated $\chi^{2}(P>0.05)$ were considered for selection. Further, of these, the model that showed the smallest deviation (least-squares estimate/standard deviation) provided by the regression technique was selected. In case of nearly equal mean deviation for two models, a model with a smaller number of parameters was considered and also the sequence of model terms for selection was taken as [m], [d], [h], [i], [j] and [1]. The standard errors for each of the six parameters $(\mathrm{m}, \mathrm{d}, \mathrm{h}, \mathrm{i}, \mathrm{j}$, and l) were estimated and the significance of each parameter was tested using t-test. The type of epistasis was determined only when dominance $[h]$ and dominance $\times$ dominance $[l]$ effects were significant. When these effects had the same sign, the effects were complementary while different signs indicated duplicate epistasis (Mather and Jinks 1982).

\begin{tabular}{|c|c|c|c|c|c|c|}
\hline \multirow[b]{2}{*}{ Cross } & \multirow[b]{2}{*}{ Generation } & \multicolumn{2}{|c|}{ Direct cross } & \multicolumn{2}{|c|}{ Reciprocal cross } & \multirow[b]{2}{*}{$\mathrm{t}$-test } \\
\hline & & Plants (number) & $\begin{array}{c}\text { Seed size } \\
(\mathrm{g} \text { per } 100 \text { seeds }) \pm \mathrm{SE}^{\mathbf{z}}\end{array}$ & Plants (number) & $\begin{array}{c}\text { Seed size } \\
(\mathrm{g} \text { per } 100 \text { seeds }) \pm \mathrm{SE}\end{array}$ & \\
\hline $\begin{array}{l}\text { ICC } 5002 \times \text { ICC } 17109 \\
\quad(\text { desi } \times \text { kabuli })\end{array}$ & $\begin{array}{l}\mathrm{F}_{1} \\
\mathrm{~F}_{2} \\
\mathrm{BC}_{1} \mathrm{P}_{1} \\
\mathrm{BC}_{1} \mathrm{P}_{2}\end{array}$ & $\begin{array}{r}9 \\
281 \\
20 \\
13\end{array}$ & $\begin{array}{r}22.3 \pm 0.46 \\
23.0 \pm 0.50 \\
9.8 \pm 0.82 \\
48.7 \pm 2.96\end{array}$ & $\begin{array}{r}23 \\
594 \\
20 \\
16\end{array}$ & $\begin{array}{r}24.2 \pm 0.75 \\
23.6 \pm 0.40 \\
9.5 \pm 0.83 \\
42.2 \pm 1.91\end{array}$ & $\begin{array}{l}\mathrm{NS}^{\mathbf{y}} \\
\mathrm{NS} \\
\mathrm{NS} \\
\mathrm{NS}\end{array}$ \\
\hline $\begin{array}{l}\text { ICC } 17109 \times \text { ICC } 11255 \\
\quad(\text { kabuli } \times \text { kabuli })\end{array}$ & $\begin{array}{l}\mathrm{F}_{1} \\
\mathrm{~F}_{2} \\
\mathrm{BC}_{1} \mathrm{P}_{1} \\
\mathrm{BC}_{1} \mathrm{P}_{2}\end{array}$ & $\begin{array}{r}9 \\
238 \\
6 \\
19\end{array}$ & $\begin{array}{l}24.8 \pm 0.94 \\
28.1 \pm 0.51 \\
39.7 \pm 3.01 \\
18.3 \pm 0.73\end{array}$ & $\begin{array}{r}24 \\
479 \\
6 \\
17\end{array}$ & $\begin{array}{l}25.1 \pm 0.53 \\
26.8 \pm 0.37 \\
39.8 \pm 4.17 \\
16.0 \pm 0.55\end{array}$ & $\begin{array}{l}\text { NS } \\
\text { NS } \\
\text { NS } \\
\text { NS }\end{array}$ \\
\hline $\begin{array}{l}\text { ICC } 7672 \times \text { ICC } 11255 \\
\quad(\text { desi } \times \text { kabuli })\end{array}$ & $\begin{array}{l}\mathrm{F}_{1} \\
\mathrm{~F}_{2} \\
\mathrm{BC}_{1} \mathrm{P}_{1} \\
\mathrm{BC}_{1} \mathrm{P}_{2}\end{array}$ & $\begin{array}{r}10 \\
121 \\
14 \\
32\end{array}$ & $\begin{array}{l}24.9 \pm 0.84 \\
26.9 \pm 0.68 \\
41.8 \pm 1.75 \\
18.4 \pm 0.71\end{array}$ & $\begin{array}{r}21 \\
794 \\
9 \\
17\end{array}$ & $\begin{array}{l}27.4 \pm 0.55 \\
25.2 \pm 0.21 \\
39.9 \pm 1.91 \\
18.4 \pm 0.77\end{array}$ & $\begin{array}{l}\text { NS } \\
\text { NS } \\
\text { NS } \\
\text { NS }\end{array}$ \\
\hline
\end{tabular}

${ }^{\mathrm{z}} \mathrm{SE}$, standard error of mean.

${ }^{\mathbf{y}} \mathrm{NS}$, non-significant at $P \leq 0.05$. 


\section{CANADIAN JOURNAL OF PLANT SCIENCE}

For the models selected, the relative importance of the gene effects was evaluated in terms of sums of squares due to each parameter adjusted for the effects of the remaining parameters of the model. Thus, these contributions were representing the direct effects of the genetic parameters under consideration. This approach differs from the earlier approach of Nigam et al. (2001) where contribution of the parameters were considered in the sequential sum of squares, in which case the contribution of the parameters following the chosen parameters were ignored. In the present study, the direct contributions of the parameters were presented relative to the all such contributions.

Additive and dominance genetic variances and narrow-sense heritability were estimated by the methods of Warner (1952). Environmental variance was estimated as per the formula of Wright (1968). The minimum number of effective factors controlling 100-seed weight was estimated by the methods of Wright (1921) and Lande (1981).

\section{RESULTS AND DISCUSSION \\ Cytoplasmic Effects}

Observations for 100 -seed weight indicated highly significant differences among the generations of all the crosses. The reciprocal differences for mean 100-seed weight of $F_{1}, F_{2}$, and backcross generations were nonsignificant for all the crosses (Table 1). This indicated that the maternal genetic factors were not involved in inheritance of seed size in all the three chickpea crosses, and hence the data of respective generations were pooled for further analysis. Seed size in legume crops is generally attributed to the cell number and cell size of cotyledons (Lemontey et al. 2000). Cell number variation mainly arises due to maternal factors, whereas non-maternal allelic variation mainly affects cell size

Table 2. Estimate of variability for seed size (grams per 100 seeds) in different generations of three chickpea crosses based on pooled reciprocal crosses data

\begin{tabular}{|c|c|c|c|c|}
\hline \multirow[b]{2}{*}{ Generation } & \multirow{2}{*}{$\begin{array}{l}\text { Population size } \\
\text { (no. of plants) }\end{array}$} & \multicolumn{3}{|c|}{ Seed size (g per 100 seeds) } \\
\hline & & Mean $(\mathrm{g}) \pm \mathrm{SE}^{\mathbf{z}}$ & Variance $^{\mathbf{y}}\left(\mathrm{g}^{2}\right)$ & Range (g) \\
\hline \multicolumn{5}{|c|}{ ICC $5002 \times$ ICC 17109} \\
\hline $\mathrm{P}_{1}(\mathrm{ICC} 5002)$ & 41 & $6.5 \pm 0.09 d$ & 0.3 & $5.4-7.9$ \\
\hline $\mathrm{P}_{2}(\mathrm{ICC} 17109)$ & 32 & $58.3 \pm 0.98 a$ & 30.4 & $48.9-68.6$ \\
\hline$F_{1}$ & 32 & $23.7 \pm 0.57 c$ & 10.5 & $16.2-36.5$ \\
\hline $\mathrm{F}_{2}$ & 875 & $23.4 \pm 0.32 c$ & 87.0 & $4.0-66.0$ \\
\hline $\mathrm{BC}_{1} \mathrm{P}_{1}$ & 40 & $9.6 \pm 0.57 d$ & 13.2 & $5.4-20.8$ \\
\hline $\begin{array}{l}\mathrm{BC}_{1} \mathrm{P}_{2} \\
m p^{\mathbf{x}}\end{array}$ & 29 & $\begin{array}{c}45.1 \pm 1.77 b \\
32.4\end{array}$ & 91.4 & $27.3-63.4$ \\
\hline F-value & & & 7.62 & \\
\hline Probability & & & $<0.0001$ & \\
\hline \multicolumn{5}{|c|}{ ICC $17109 \times$ ICC 11255} \\
\hline $\mathrm{P}_{1}(\mathrm{ICC} 17109)$ & 25 & $57.9 \pm 1.02 a$ & 25.8 & $50.7-71.1$ \\
\hline $\mathrm{P}_{2}(\mathrm{ICC} 11255)$ & 48 & $13.7 \pm 0.15 d$ & 1.1 & $11.5-16.3$ \\
\hline$F_{1}$ & 33 & $25.0 \pm 0.46 c$ & 6.9 & $20.2-30.1$ \\
\hline $\mathrm{F}_{2}$ & 717 & $27.2 \pm 0.30 c$ & 63.7 & $6.0-64.9$ \\
\hline $\mathrm{BC}_{1} \mathrm{P}_{1}$ & 12 & $39.8 \pm 2.45 b$ & 72.2 & $25.0-51.7$ \\
\hline $\begin{array}{l}\mathrm{BC}_{1} \mathrm{P}_{2} \\
m p\end{array}$ & 36 & $17.2 \pm 0.50 d$ & 8.9 & $12.7-23.7$ \\
\hline F-value & & 53.0 & 7.03 & \\
\hline Probability & & & $<0.0001$ & \\
\hline \multicolumn{5}{|c|}{ ICC $7672 \times$ ICC 11255} \\
\hline $\mathrm{P}_{1}(\mathrm{ICC} 7672)$ & 17 & $46.1 \pm 0.92 a$ & 14.3 & $41.3-54.9$ \\
\hline $\mathrm{P}_{2}(\mathrm{ICC} 11255)$ & 43 & $12.9 \pm 0.13 e$ & 0.8 & $10.8-14.7$ \\
\hline$F_{1}$ & 31 & $26.6 \pm 0.50 c$ & 7.7 & $22.1-32.2$ \\
\hline $\mathrm{F}_{2}$ & 915 & $25.4 \pm 0.21 c$ & 38.6 & $8.7-52.3$ \\
\hline $\mathrm{BC}_{1} \mathrm{P}_{1}$ & 23 & $41.0 \pm 1.29 b$ & 38.1 & $30.5-56.5$ \\
\hline $\mathrm{BC}_{1} \mathrm{P}_{2}$ & 49 & $18.4 \pm 0.53 d$ & 13.9 & $12.5-26.1$ \\
\hline$m p$ & & 29.5 & & \\
\hline F-value & & & 6.58 & \\
\hline Probability & & & $<0.0001$ & \\
\hline
\end{tabular}

${ }^{\mathbf{z}} \mathrm{SE}$, standard error of mean.

${ }^{\mathbf{y}}$ Variances were tested using Levene's test.

$\mathbf{x} m p=$ mid parent value and was calculated as $\left(\mathrm{P}_{1}+\mathrm{P}_{2}\right) / 2$.

$a-e$ Means were tested using Newman-Keul's test and the means followed by a different letter within each cross were significantly different at $P \leq 0.05$. 
(Alonso-Blanco et al. 1999). Therefore, non-significant reciprocal differences in all the crosses indicated that the seed size differences in chickpea could be due to variation in cell size of cotyledon.

\section{Means and Variances}

The estimates of mean 100-seed weight for the parents indicated that the average seed size of ICC 5002 was significantly smaller than those of ICC 11255 , ICC 7672, and ICC 17109. In all the three crosses, mean seed size of the $F_{1}$ and $F_{2}$ generations were between the midparental value and the small seeded parent (Table 2), suggesting partial dominance of alleles for small seed size.

The mean 100-seed weight of backcross generations was intermediate between the $F_{1}$ generation mean and recurrent parent mean in all the crosses. The extent of variation in seed size of the $F_{2}$ generations was much higher than that observed in their parents and $F_{1}$ generation. However, none of the three crosses showed discrete classes of seed size, and frequency distribution was continuous in $\mathrm{F}_{2}$ generation with no distinct modes (Fig. 1), which indicated the quantitative inheritance (controlled by minor genes) for this character in the three crosses. These findings were similar to earlier
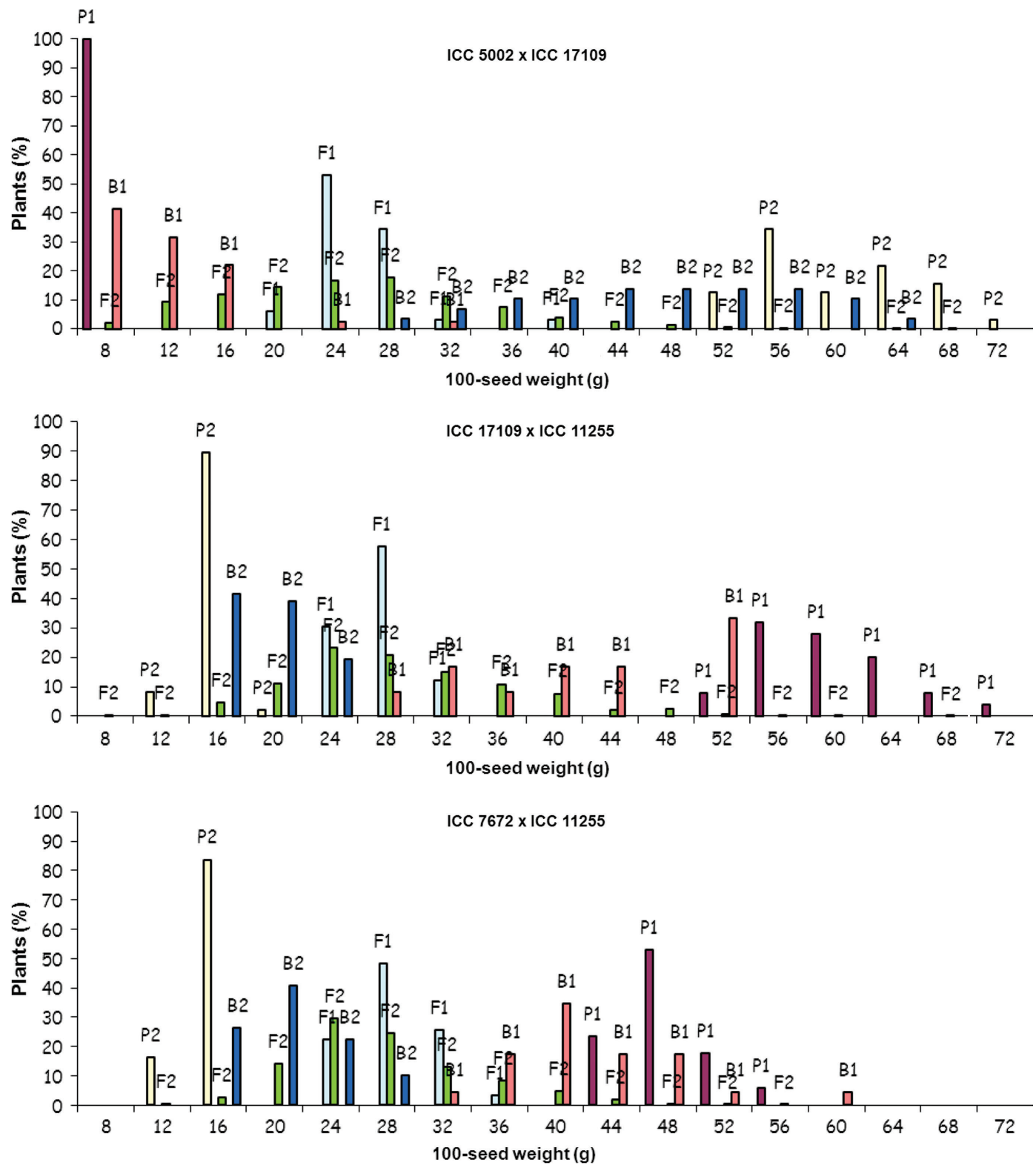

Fig. 1. Histograms of seed size distribution for six generations $\left(\mathrm{P}_{1}, \mathrm{P}_{2}, \mathrm{~F}_{1}, \mathrm{~F}_{2}, \mathrm{BC}_{1} \mathrm{P}_{1}\right.$, and $\left.\mathrm{BC}_{1} \mathrm{P}_{2}\right)$ in three chickpea crosses based on pooled reciprocal crosses data from field experiment conducted during 2000-2001 ( $\mathrm{B} 1$ refers to $\mathrm{BC}_{1} \mathrm{P}_{1}$; and $\mathrm{B} 2$ refers to $\mathrm{BC}_{1} \mathrm{P}_{2}$ ).

Author: Figure 1 will be in colour on the web at no charge but the cost print in colour is $\$ 750.00$ - Please let us know if you want to print in colour or black and white 
reports of Kumar and Singh (1995) and Malhotra et al. (1997), which also showed partial dominance of alleles for small seed size and polygenic inheritance for seed size in chickpea.

\section{Generation Mean Analysis}

Generation mean analysis indicated different modes of inheritance for seed size in the three crosses (Table 3). The regression analysis tested different parameters to find the best fit model to explain genetic control of seed size in the three crosses. Mean effects [m] were highly significant for seed size in all the three crosses. Additive effects were significant in all the three crosses and were negative in the cross ICC $5002 \times$ ICC 17109 and positive in the remaining two crosses, ICC $17109 \times$ ICC 11255 , and ICC $7672 \times$ ICC 11255 . But, a negative sign for additive effects merely reflects which of the parents is chosen as $\mathrm{P}_{1}$ and has no genetic consequences. The dominance effect was significant only in one cross, ICC $7672 \times$ ICC 11255 indicating its differential importance in the inheritance of seed size in these three crosses. The sign of dominance effect is a function of $F_{1}$ generation mean value in relation to the mid parent value and it indicates which parent is contributing to the dominance effects. The dominance effect was significant and positive in the cross ICC $7672 \times$ ICC 11255 , which indicated that $F_{1}$ was similar to the increasing parent/ large seed size parent i.e., ICC 7672, as dominance was controlled by the parent having alleles responsible for high value of the trait. In ICC $7672 \times$ ICC 11255 cross, dominance effects were significant and greater than the additive affects (Table 3 ) indicating preponderance of dominance effects for seed size in this cross.

The result of fitting the models indicated that epistasis was present for seed size in all the three crosses
(Table 3), although the significance of interactions varied in the crosses. In the cross ICC $5002 \times$ ICC 17109, [i] $(9.4 \pm 0.98)$ and [j] $(-13.8 \pm 2.37)$ types of epistatic interactions were important $(P \leq 0.05)$, whereas the epistatic interactions ( $\mathrm{i}$ and 1$)$ were non-significant $(P>0.05)$ in the cross ICC $17109 \times$ ICC 11255 and all three types of epistatic interactions (i, j and 1$)$ were significant $(P \leq 0.05)$ in the cross ICC $7672 \times$ ICC 11255 (Table 3). The genes controlling seed size in the cross ICC $7672 \times$ ICC 11255 showed duplicate interaction as reflected by opposite sign of [h] and [1] in this cross (Table 3) (Mather and Jinks 1982).

The partitioning of genetic variance into additive and dominance components was not possible due to the presence of epistasis. Therefore, relative contributions of [d], [h], [i], [j] and [l] to the total genetic variation were calculated by using sequential sums of squares (Table 4). The variability accounted for by the different estimated effects varied in the three crosses (Table 4). The additive portion of genetic effects [d], which is fixable, accounted for largest portion of the genetic variability $(>93 \%)$ for seed size in all the three crosses, adequately supported by higher magnitude of additive genetic variances $\left(\mathrm{V}_{\mathrm{A}}\right)$ relative to dominance variance $\left(\mathrm{V}_{\mathrm{D}}\right)$, and by fairly high narrow-sense heritability $(\geq 66 \%)$ (Table 5 ). The nonadditive portion of genetic variance i.e., dominance $[\mathrm{h}]$ and epistasis (i, j and 1$)$ accounted only for small portion of total variance. However, the largest contribution of dominance effect for seed size was in the cross ICC $7672 \times$ ICC 11255 . The [i] type epistasis, which are fixable, accounted for $3.0 \%$ and $2.5 \%$ variability and [j] type epistasis accounted for $1.1 \%$ and $1.2 \%$ variability in the crosses ICC $5002 \times$ ICC 17109 , and ICC $7672 \times$ ICC 11255 , respectively. The largest contribution of [1] type epistasis $(1.2 \%)$ was in the cross ICC $7672 \times$

Table 3. Estimates of mean (mean \pm SE) of scaling test and different genetic parameter governing inheritance of seed size (grams per 100 seeds) based on pooled reciprocal crosses data in chickpea

Seed size (g per 100 seeds)

\begin{tabular}{|c|c|c|c|}
\hline & \multicolumn{3}{|c|}{ Seed size (g per 100 seeds) } \\
\hline & ICC $5002 \times$ ICC 17109 & ICC $17109 \times$ ICC 11255 & ICC $7672 \times$ ICC 11255 \\
\hline \multicolumn{4}{|l|}{ Scaling test } \\
\hline $\mathrm{A}=2 \mathrm{BC}_{1} \mathrm{P}_{1}-\mathrm{P}_{1}-\mathrm{F}_{1}$ & $-10.9 \pm 1.29 *(P<0.001)$ & $-3.5 \pm 5.03(P=0.246)$ & $9.4 \pm 2.78 *(P<0.001)$ \\
\hline $\mathrm{B}=2 \mathrm{BC}_{1} \mathrm{P}_{2}-\mathrm{P}_{2}-\mathrm{F}_{1}$ & $8.3 \pm 3.73 *(P=0.013)$ & $-4.3 \pm 1.11 *(P<0.001)$ & $-2.6 \pm 1.18 *(P=0.014)$ \\
\hline $\mathrm{C}=4 \mathrm{~F}_{2}-2 \mathrm{~F}_{1}-\mathrm{P}_{1}-\mathrm{P}_{2}$ & $-18.6 \pm 1.97 *(P<0.001)$ & $-12.7 \pm 1.82 *(P<0.001)$ & $-10.4 \pm 1.59 *(P<0.001)$ \\
\hline $\mathrm{D}=2 \mathrm{~F}_{2}-\mathrm{BC}_{1} \mathrm{P}_{1}-\mathrm{BC}_{1} \mathrm{P}_{2}$ & $-8.0 \pm 1.97^{*}(P<0.001)$ & $-2.5 \pm 2.57(P=0.168)$ & $-8.6 \pm 1.45^{*}(P<0.001)$ \\
\hline \multicolumn{4}{|l|}{ Statistical analysis } \\
\hline$\chi^{2}$ & 3.01 & 0.03 & $-{ }^{\mathbf{z}}$ \\
\hline Probability $\left(\chi^{2}>\chi_{0}^{2}\right)$ & 0.08 & 0.87 & - \\
\hline Coefficient of determination $\left(\mathrm{R}^{2}\right)$ & 1.00 & 1.00 & - \\
\hline \multicolumn{4}{|l|}{ Gene effects } \\
\hline Mean [m] & $23.1 \pm 0.85^{*}(P<0.001)$ & $31.7 \pm 2.34 *(P<0.001)$ & $12.4 \pm 2.94 *(P<0.001)$ \\
\hline Additive effect [d] & $-26.0 \pm 0.49^{*}(P<0.001)$ & $22.1 \pm 0.50 *(P<0.001)$ & $16.6 \pm 0.46^{*}(P<0.001)$ \\
\hline Dominance effect $[\mathrm{h}]$ & $0.7 \pm 1.31(P=0.597)$ & $-11.0 \pm 6.50(P=0.090)$ & $38.1 \pm 8.64 *(P<0.001)$ \\
\hline Additive $\times$ additive effect [i] & $9.4 \pm 0.98 *(P<0.001)$ & $4.2 \pm 2.47(P=0.090)$ & $17.1 \pm 2.90 *(P<0.001)$ \\
\hline Additive $\times$ dominance effect $[j]$ & $-13.8 \pm 2.37^{*}(P<0.001)$ & - & $12.0 \pm 2.93 *(P<0.001)$ \\
\hline Dominance $\times$ dominance effect $[1]$ & $-\quad-$ & $4.4 \pm 4.29(P=0.304)$ & $-23.9 \pm 5.79 *(P<0.001)$ \\
\hline
\end{tabular}

${ }^{\mathbf{z}}$ The components excluded in the model used.

*Significant at $P \leq 0.05$. 
Table 4. Variability (\%) accounted for by the different genetic components for seed size (grams per 100 seeds) based on pooled reciprocal crosses data in chickpea

\begin{tabular}{lccc}
\hline & & Variability (\%) \\
\cline { 2 - 4 } Genetic components & ICC $5002 \times$ ICC 17109 & ICC $17109 \times$ ICC 11255 & ICC $7672 \times$ ICC 11255 \\
\hline Additive effect [d] & 95.7 & 99.7 & 93.6 \\
Dominance effect [h] & 0.0 & 0.2 & 1.4 \\
Additive $\times$ additive effect [i] & 3.0 & 0.2 & 2.5 \\
Additive $\times$ dominance effect [j] & 1.1 & $-\mathbf{z}$ & 1.2 \\
Dominance $\times$ dominance effect [l] & - & 0.1 & 1.2 \\
\hline
\end{tabular}

${ }^{\mathbf{z}}$ The components excluded in the model used.

ICC 11255 (Table 4). The higher value of narrow-sense heritability $\left(\mathrm{h}_{\mathrm{ns}}^{2}\right)$ indicated that selection will be useful for seed size, coupled with high expected genetic advance (Table 5), which was in conformity with Kumar and Singh (1995). Considering the extreme parental diversity of the crosses, the widest possible variations for seed size were uncovered in the segregating generations. The high variability, largely represented by the fixable components coupled with high narrow-sense heritability in the present study indicated that the selection in the $\mathrm{F}_{2}$ will likely lead to a substantial improvement in seed size in chickpea. The expected genetic gain (Table 5) shows the possible outcome from the selection as percent increase in the $\mathrm{F}_{3}$ over the $\mathrm{F}_{2}$ mean, when the most desirable $5 \%(\mathrm{~K}$, selection differential $=2.06)$ of the $\mathrm{F}_{2}$ plants were selected. Taking the assumption of no dominance, no linkage, and no epistasis, it is possible to estimate the minimum number of effective factors involved in the seed size inheritance using population variances (Wright 1968). The estimates of the minimum number of effective factors controlling seed size in three chickpea crosses were approximately 5 (Table 5). These estimates may be biased due to presence of epistatic effects, but the estimates using the formula given by Lande (1981) are more reliable as they may be less affected by the presence of dominance. In earlier findings, various researchers (Cho et al. 2002; Cobos et al. 2007, 2009; Radhika et al. 2007; Hossain et al. 2010) identified two QTL for seed size in chickpea. In all these studies, one QTL was detected on linkage group (LG) 4 while the other QTL was detected on different LG such as on LG 9 (Cho et al. 2002), LG 8 (Cobos et al. 2007), LG 1 (Radhika et al. 2007; Hossain et al. 2010), and LG 2 (Cobos et al. 2009). Therefore, the findings from these studies collectively show five QTL detected for seed size on five LG (LG4, LG9, LG 8, LG1, and LG2), which is consistent with the present studies' results (Table 5).

As a general rule, traits controlled by a small number of genes show high heritability in early generations, permitting the fixation of distinct genotypes by using a small number of selfing generations (Anand and Torrie 1963). Quantitative traits, such as seed size, are expected to be influenced to a large extent by environmental effects. Environmental variances, however, accounted for only approximately $15 \%$ in the cross ICC $5002 \times$ ICC $17109,16 \%$ in the cross ICC $17109 \times$ ICC 11255 , and $20 \%$ in the cross ICC $7672 \times$ ICC 11255 , which indicate the importance of genetic effects in the inheritance of seed size in these three crosses (Table 5).

In the present study, the six generations $\left(\mathrm{P}_{1}, \mathrm{P}_{2}, \mathrm{~F}_{1}, \mathrm{~F}_{2}\right.$, $\mathrm{BC}_{1} \mathrm{P}_{1}$, and $\left.\mathrm{BC}_{1} \mathrm{P}_{2}\right)$ were evaluated in one season $(2000$ 2001) at one location due to the resource constraints and thus have limitations due to genotype $\times$ environment

Table 5. Variance components, heritability estimates and minimum number of effective factors for seed size (grams per 100 seeds) based on pooled reciprocal crosses data in chickpea

Seed size (g per 100 seeds) in three crosses

\begin{tabular}{|c|c|c|c|c|}
\hline Estimates & Formula $^{\mathbf{z}}$ & ICC $5002 \times$ ICC 17109 & ICC $17109 \times$ ICC 11255 & ICC $7672 \times$ ICC 11255 \\
\hline Genetic variance $\left(\mathrm{V}_{\mathrm{G}}\right)$ & $\mathrm{V}_{\mathrm{F} 2}-\mathrm{V}_{\mathrm{E}}$ & 74.1 & 53.5 & 31.0 \\
\hline Additive variance $\left(\mathrm{V}_{\mathrm{A}}\right)$ & $2 \mathrm{~V}_{\mathrm{F} 2}-\mathrm{V}_{\mathrm{BC} 1 \mathrm{P} 1}-\mathrm{V}_{\mathrm{BC} 1 \mathrm{P} 2}$ & 69.5 & 46.3 & 25.3 \\
\hline Dominance variance $\left(\mathrm{V}_{\mathrm{D}}\right)$ & $\mathrm{V}_{\mathrm{BC} 1 \mathrm{P} 1}+\mathrm{V}_{\mathrm{BC} 1 \mathrm{P} 2}-\mathrm{V}_{\mathrm{F} 2}-\mathrm{V}_{\mathrm{E}}$ & 4.6 & 7.2 & 5.7 \\
\hline Environmental variance $\left(\mathrm{V}_{\mathrm{E}}\right)$ & $0.25 \mathrm{~V}_{\mathrm{P} 1}+0.25 \mathrm{~V}_{\mathrm{P} 2}+0.5 \mathrm{~V}_{\mathrm{F} 1}$ & 13.0 & 10.2 & 7.6 \\
\hline Phenotypic variance $\left(\mathrm{V}_{\mathrm{P}}\right)$ & $\mathrm{V}_{\mathrm{G}}+\mathrm{V}_{\mathrm{E}}$ & 87.1 & 63.7 & 38.6 \\
\hline Heritability $\left(\mathrm{h}_{\mathrm{ns}}^{2}\right)(\%)$ & $\mathrm{V}_{\mathrm{A}} / \mathrm{V}_{\mathrm{F} 2}$ & 80.0 & 73.0 & 66.0 \\
\hline Heritability $\left(\mathrm{h}_{\mathrm{bs}}^{2}\right)(\%)$ & $\mathrm{V}_{\mathrm{G}} / \mathrm{V}_{\mathrm{F} 2}$ & 85.0 & 84.0 & 80.0 \\
\hline Expected genetic gain (g) & $\mathrm{K} \times \sigma_{\mathrm{p}} \times \mathrm{h}_{\mathrm{ns}}^{2}$ & 15.3 & 12.0 & 8.4 \\
\hline \multicolumn{5}{|c|}{ Minimum Number of effective factors } \\
\hline Lande (1981) (Number) & $\mathrm{D}^{2} / 8 \mathrm{~V}_{\mathrm{A}}$ & 4.8 & 5.3 & 5.4 \\
\hline Wright (1921) (Number) & {$\left[0.25\left(0.75-\mathrm{h}+\mathrm{h}^{2}\right) \mathrm{D}^{2}\right] /\left(\mathrm{V}_{\mathrm{F} 2}-\mathrm{V}_{\mathrm{F} 1}\right)$} & 4.6 & 4.8 & 4.5 \\
\hline
\end{tabular}

${ }^{\mathrm{z}} \mathrm{V}_{\mathrm{P} 1}, \mathrm{~V}_{\mathrm{P} 2}, \mathrm{~V}_{\mathrm{F} 1}, \mathrm{~V}_{\mathrm{F} 2}, \mathrm{~V}_{\mathrm{BC} 1 \mathrm{P} 1}$ and $\mathrm{V}_{\mathrm{BC} 1 \mathrm{P} 2}$ represent the variances of $\mathrm{P}_{1}, \mathrm{P}_{2}, \mathrm{~F}_{1}, \mathrm{~F}_{2}$ and backcross to $\mathrm{P}_{1}$ and $\mathrm{P}_{2}$, respectively; $\mathrm{K}=$ selection differential; $\sigma_{\mathrm{p}}=$ phenotypic standard deviation; $\mathrm{D}$ is the difference between observed parental means $=\left(\mathrm{P}_{1}-\mathrm{P}_{2}\right) ; \mathrm{h}$ is the dominance ratio $=\left(\mathrm{F}_{1}-\mathrm{P}_{1}\right) / \mathrm{D}$. 
$(\mathrm{g} \times \mathrm{e})$ interactions. However, the high estimates of heritability for this trait coupled with low environmental variances in the present study as well as in the earlier findings (Niknezad et al. 1971; Kumar and Singh 1995; Cobos et al. 2007; Hossain et al. 2010) indicate the usefulness of these findings. Overall, the present study revealed absence of reciprocal differences in the inheritance of seed size in all the three chickpea crosses. Continuous variation in $\mathrm{F}_{2}$ generation showed quantitative inheritance for seed size. Being based on firstdegree statistics (mean values), the estimates of digenic non-allelic interaction effects are less confounded with one another (Mather and Jinks 1982) and therefore, more reliable. The preponderance of additive (95.7-99.7\%) and additive $\times$ additive gene effects $(0.2-3.0 \%)$ coupled with high narrow-sense heritability and genetic advance for seed size in ICC $5002 \times$ ICC 17109 and ICC $17109 \times$ ICC 11255 indicated that simple breeding methods such as selection following hybridization for genetic improvement of seed size may be utilized and effective selection could be practiced even in the early generations for improving seed size. However, the importance of dominance effect with duplicate epistasis for seed size in the cross ICC $7672 \times$ ICC 11255 indicated that selection and breeding procedures should be modified to exploit nonadditive genetic variance by delaying the selection to later generations. Because selection for seed size was reported to be the best method for improving seed yield in chickpea (Bisen et al. 1985; Kumar and Bahl 1992), indirect selection for yield through seed size would also be useful.

Alonso-Blanco, C., de Vries, H. B., Hanhart, C. J. and Koorneef, M. 1999. Natural allelic variation at seed loci in relation to other life history traits of Arabidopsis thaliana. Proc. Nat. Acad. Sci. (USA) 96: 4710-4717.

Anand, S. C. and Torrie, J. H. 1963. Heritability of yield and other traits and interrelationship among traits in the $\mathrm{F}_{3}$ and $\mathrm{F}_{4}$ generations of three soybean crosses. Crop Sci. 3: 508-511.

Argikar, G. P. 1956. Some qualitative and quantitative observation on the genetic improvement of green seeded strain of Cicer arietinum L. Indian J. Genet. Pl. Br. 16: 52-56.

Bisen, M. S., Singh, S. P. and Rao, S. K. 1985. Selection grains in chickpea (Cicer arietinum Linn.). Egypt J. Genet. Cytol. 14: 51-58.

Cavalli, L. L. 1952. An analysis of linkage in quantitative inheritance. Pages 135-144 in E. C. R. Reeve and C. H. Waddington, eds. Quantitative inheritance. Her Majesty's Stationary Office, London, UK.

Cho, S., Kumar, J., Shultz, J., Anupama, K., Tefera, F. and Muehlbauer, F. 2002. Mapping genes for double podding and other morphological traits in chickpea. Euphytica 128: 285-292.

Cobos, M. J., Rubio, J., Fernandez-Romero, M. D., Garza, R., Moreno, M. T., Millan, T. and Gil, J. 2007. Genetic analysis of seed size, yield and days to flowering in a chickpea recombinant inbred line population derived from a kabuli $\times$ desi cross. Ann. Appl. Biol. 151: 33-42.

Cobos, M. J., Winter, P., Kharrat, M., Cubero, J. L., Gil, J., Millan, T. and Rubio, J. 2009. Genetic analysis of agrono- mic traits in a wide cross of chickpea. Field Crops Res. 111: 130-136.

Dahiya, B. S., Solanki, I. S. and Kumar, R. 1985. Germination rate and its genetics in chickpea. Intl. Chickpea Newsl. 13: 6-8. Davies, D. R. 1975. Studies of seed development in Pisum sativum. I. Seed size in reciprocal crosses. Planta 124: 297-302. El-Swaify, S. A., Pathak, P., Rego, T. J. and Singh, S. 1985. Soil management for optimized productivity under rainfed conditions in the Semi-Arid Tropics. Pages 1-64 in B. A. Stewart, ed. Advances in soil science. Vol. I. Springer-Verlag, New York, NY.

Food and Agriculture Organization. 2010. Global area, production and productivity of chickpea. [Online] Available: http:// faostat.fao.org/site/567/DesktopDefault.aspx [2012 Jun. 12].

Ghatge, R. D. 1993. Inheritance of seed size in chickpea (Cicer arietinum L.). J. Soils Crops 3: 56-59.

Hayman, B. I. and Mather, K. 1955. The description of genetics of interaction in continuous variation. Biometrics 51: 69-82.

Hossain, S., Ford, R., McNeil, D., Pittock, C. and Panozzo, J. F. 2010. Inheritance of seed size in chickpea (Cicer arietinum L.) and identification of QTL based on 100-seed weight and seed size index. Austr J. Crop Sci. 4: 126-135.

Kumar, J. and Bahl, P. N. 1992. Direct and indirect selection for yield in chickpea. Euphytica 60: 197-199.

Kumar, S. and Singh, O. 1995. Inheritance of seed size in chickpea. J. Genet. Breed. 49: 99-104.

Lande, R. 1981. The minimum number of genes contributing to quantitative variation between and within populations. Genetics 99: 541-553.

Lemontey, C., Mousset-Declas, C., Munier-Jolain, N. and Boutin, J. 2000. Maternal genotype influences pea seed size by controlling both mitotic activity during early embryogenesis and final endoreduplication level/ cotyledon cell size in mature seed. J. Exp. Bot. 51: 167-175.

Malhotra, R. S., Bejiga, G. and Singh, K. B. 1997. Inheritance of seed size in chickpea. J. Genet. Breed. 51: 45-50.

Mather, K. 1949. Biometrical genetics. Methuen and Company, London, UK. 158 pp.

Mather, K. and Jinks, J. L. 1982. Biometrical genetics. The study of continuous variation. 3rd ed. Chapman and Hall, London, UK. 396 pp.

Narayana, A., Saxena, N. P. and Sheldrake, A. R. 1981. Varietal differences in seed size and seedling growth of pigeonpea and chickpea. Indian J. Agric. Sci. 51: 89-393.

Nigam, S. N., Upadhyaya, H. D., Chandra, S., Nageswara Rao, R. C., Wright, G. C. and Reddy, A. G. S. 2001. Gene effects for specific leaf area and harvest index in three crosses of groundnut (Arachis hypogaea). Ann. Appl. Biol. 139: 301-306. Niknezad, M., Khosh-Khur, M. and Ghorashy, S. R. 1971. Inheritance of seed size in chickpea (Cicer arietinum L.). Crop Sci. 11: 768-769.

Patil, J. A. and D'Cruze, R. 1964. Inheritance of seed size in gram (Cicer arietinum L.). Poona Agric. Coll. Mag. 54: 21-22.

Payne, R. W., Harding, S. A., Murray,D. A., Soutar, D. M., Baird, D. B., Glaser, A. I., Channing, I. C., Welham, S. J., Gilmour, A. R., Thompson, R. and Webster, R. 2009. The Guide to GenStat ${ }^{\circledR}$ Release 12, Part 2: Statistics. VSN International, Hemel Hempstead, UK. 256 pp.

Radhika, P., Gowda, S. J. M., Kadoo, N. Y., Mhase, L. B., Jamadagni, B. M., Sainanai, M. N., Chandra, S. and Gupta, V. S. 2007. Development of an integrated intraspecific map of 
chickpea (Cicer arietinum L.) using two recombinant inbred line populations. Theor. Appl. Genet. 115: 209-216.

Singh, K. B. 1987. Chickpea breeding. Pages 127-162 in M. C. Saxena and K. B. Singh, eds. The chickpea. CAB International, Wallingford, UK.

Singh, O. and Paroda, R. S. 1986. Association analysis of grain yield and its components in chickpea following hybridization and a combination of hybridization and mutagenesis. Indian $\mathrm{J}$. Agric. Sci. 56: 139-141.

Singh, O., Gowda, C. L. L., Sethi, S. C., Dasgupta, T., Kumar, J. and Smithsons, J. B. 1992. Genetic analysis of agronomic characters in chickpea. I. Estimates of genetic variances from diallel mating designs. Theor. Appl. Genet. 83: 956-962.

Singh, O., Gowda, C. L. L., Sethi, S. C., Dasgupta, T., Kumar, J. and Smithsons, J. B. 1993. Genetic analysis of agronomic characters in chickpea. II. Estimates of genetic variances from line $\times$ tester mating designs. Theor. Appl. Genet. 85: 1010-1016.

Upadhyaya, H. D. 2003. Geographical patterns of variation for morphological and agronomic characteristics in the chickpea germplasm collection. Euphytica 132: 343-352.
Upadhyaya, H. D., Kumar, S., Gowda, C. L. L. and Singh, S. 2006. Two major genes for seed size in chickpea (Cicer arietinum L.). Euphytica 147: 311-315.

Upadhyaya, H. D., Sharma, S., Singh, S. and Singh, M. 2010. Inheritance of drought resistance related traits in two crosses of groundnut (Arachis hypogaea L.). Euphytica 177: 55-66.

Upadhyaya, H. D., Sharma, S. and Gowda, C. L. L. 2011. Major genes with additive effects for seed size in kabuli chickpea (Cicer arietinum L.). J. Genet. 90: 479-482.

Warner, J. N. 1952. A method of estimating heritability. Agron. J. 44: 427-430.

Wright, S. 1921. System of mating. Genetics 6: 111-178.

Wright, S. 1968. The genetics of quantitative variability. Pages 373-420 in S. Wright, ed. Evolution and genetics of populations. Vol I. University of Chicago Press, Chicago, IL.

Yadav, S. S., Redden, R., Chen, W. and Sharma, B. 2007. Chickpea breeding and management. CAB International Publishers, Wallingford, UK. 638 pp. 